\title{
HEAVY METALS UPTAKE BY HYPERACCUMULATING FLORA IN SOME SERPENTINE SOILS OF KOSOVO
}

\author{
SALIHAJ M. ${ }^{1, *}$ \\ BANI A. ${ }^{2}$ \\ ECHEVARRIA G. ${ }^{3}$
}

\author{
${ }^{1}$ Agricultural University of Tirana \\ Koder-Kamze, Tirana, Albania \\ ${ }^{2}$ Agro-Environmental Department, \\ Faculty of Agronomy and Environment \\ Agricultural University of Tirana, Koder-Kamze, Tirana, Albania \\ ${ }^{3}$ Laboratoire Sols et Environnement \\ Nancy-Université, INRA, 2 avenue de la Forêt de Haye \\ B.P. 172 F-54505, Vandoeuvre-lès-Nancy, France
}

Received: $18 / 10 / 2015$

Accepted: $12 / 12 / 2015$

Available online: $21 / 01 / 2016$ *to whom all correspondence should be addressed: e-mail: muharremsalihaj@hotmail.com

\begin{abstract}
Ultramafics represent magmatic or metamorphic rocks which are characterized by high concentrations of $\mathrm{Mg}, \mathrm{Fe}, \mathrm{Ni}, \mathrm{Cr}$ and $\mathrm{Co}$ and low concentrations of $\mathrm{Ca}$, and $\mathrm{K}$. Serpentine soils are weathered products of a range of ultramafic rocks composed of ferromagnesian silicates. The aim of this study was to determine the content of heavy metals in some of serpentine soils of Kosovo and heavy metals uptake by entire associated flora. Furthermore, another objective of this study was finding out bioavailable $\mathrm{Ca} / \mathrm{Mg}$ relationship, which is very important indicator for plants' development. The sampling was conducted in June 2014. A total of three serpentine areas have been surveyed and 7 soil samples have been taken in various depths of soil profiles. Those samples were analyzed for total $\mathrm{Ca}, \mathrm{Cd}, \mathrm{Co}, \mathrm{Cr}, \mathrm{Cu}, \mathrm{Mn}, \mathrm{Ni}, \mathrm{Pb}, \mathrm{Fe}$ and $\mathrm{Zn}$. Results showed that each site exhibited a high concentration of at least one metal. The maximum concentrations of metals in soils Dry Matter (DM) were $108.9 \mathrm{mg} \mathrm{kg}^{-1} \mathrm{Cd}, 95.8 \mathrm{mg} \mathrm{kg}^{-1}$ Co, $1206 \mathrm{mg} \mathrm{kg}^{-1}$ $\mathrm{Cr}, 24 \mathrm{mg} \mathrm{kg}^{-1} \mathrm{Cu}, 2570 \mathrm{mg} \mathrm{kg}^{-1} \mathrm{Ni}, 21.7 \mathrm{mg} \mathrm{kg}^{-1} \mathrm{~Pb}, 39 \mathrm{mg} \mathrm{kg}^{-1} \mathrm{Zn}$, and $51563 \mathrm{mg} \mathrm{kg}^{-}$Fe. The serpentine soils at all sites were characterized by elevated levels of heavy metals, which showed typical properties of ultramafic environments. Nickel Total at studied areas varied between 1543 and $2570 \mathrm{mg} \mathrm{kg}^{-1}$, while the highest Ni concentration was found in aerial part of Alyssum markgrafii (4038 $\mathrm{mgkg}^{-1}$ ),

Based on our findings on the field we concluded that there is a close relationship between the quantity of $\mathrm{Ni}$ in soil and $\mathrm{Ni}$ uptake in plants.
\end{abstract}

Keywords: Serpentine soils, Heavy metals, Ultramafics, Metals bioavailabillity

\section{Introduction}

Ultramafics represent magmatic or metamorphic rocks which are characterized by high concentrations of $\mathrm{Mg}, \mathrm{Fe}, \mathrm{Ni}, \mathrm{Cr}$ and $\mathrm{Co}$ and low concentrations of $\mathrm{Ca}$ and $\mathrm{K}$ containing less than $45 \%$ silica $\left(\mathrm{SiO}_{2}\right)$.

The term "serpentine" strictly speaking refers only to the serpentine group of minerals (including antigorite and chrysolite) with the general formula $\mathrm{Mg}_{3} \mathrm{Si}_{2} \mathrm{O}_{5}(\mathrm{OH})_{4}$, which are important constituents of weathered "ultramafic rocks". These minerals are derived from the "serpentinization" of ultramafic rocks. Rocks which are rich in serpentine minerals derived from alteration of previously existing olivines and 
pyroxenes are known as "serpentines". Serpentines are rocks that form as a result of metamorphism or metasomatism of primary magnesium-iron silicate minerals.

Throughout the territory of Kosovo there are many basic and ultra-basic rocks, commonly known as "serpentines". The aim of this study was to determine the content of heavy metals and other macro elements in some of serpentine soils, and as well as finding out bioavailable $\mathrm{Ca} / \mathrm{Mg}$ relationship, which is very important indicator for normal plants development. The studied areas of serpentine soils include three separate zones with an area of $15.67 \mathrm{~km}^{2}$ comprising thus $7.66 \%$ out of total serpentine soils in Kosovo.

\subsection{Chemical properties of serpentine soils - the serpentine factor}

The serpentine factor may be defined as the causal factor (physical or chemical) related to the infertility of serpentine soils. The general infertility of serpentine soils may also be defined as the serpentine problem" (Brooks, 1987). Kazakou et al. in 2010 presented three of the most popular hypotheses in order to explain the edaphic factors which may control serpentine floras: 1) Low availability of calcium in relation to magnesium; 2) Deficiency of essential macronutrients; 3) High levels of phytotoxic heavy metals ( $\mathrm{Ni}, \mathrm{Cr}, \mathrm{Co}, \mathrm{Mn}$ ).

a) The toxicity of Magnesium

The high level of magnesium was considered to be one of the most likely negative causes of the serpentine problem. This topic was elaborated in detail by Krause, (1958) and has been dealt with over the past 150 years. Part of this toxicity comes from the very high magnesium concentration in some soils, containing up to $36 \%$ of $\mathrm{MgO}$. As per my results obtained at examined areas, the total $\mathrm{Mg}$ content ranges from 16 to $19.4 \%$.

\section{b) Deficiency of Calcium}

The concentration of calcium in serpentine soils is extremely low and in some cases is $<100 \mathrm{mg} \mathrm{kg}^{-1}$. However, low calcium levels are not the primary cause of serpentine infertility. It is rather the low $\mathrm{Ca} / \mathrm{Mg}$ quotients that primarily cause this serpentine syndrome. Experiments conducted by Proctor, (1971) have proved that addition of calcium could largely reduce the incidence of nickel toxicity symptoms in vegetation. The Ca content in serpentine soils of Kosovo varies from 628.83 to $5422.27 \mathrm{mgkg}^{-1}$.

c) Unfavorable $\mathrm{Ca} / \mathrm{Mg}$ Quotient.

Loew \& May (1901) first reported that poor productivity of serpentine soils is due to the low Ca:Mg ratio present in them. From their experiments, they concluded that the $\mathrm{Ca}: \mathrm{Mg}$ ratio must be at least in unity for optimal growth of plants.(The bioavailable $\mathrm{Ca} / \mathrm{Mg}$ ratio in studied serpentine soils of Kosovo is in range of 0.63-3.17)

\section{Materials and methods}

The sampling was conducted in June 2014. A total of three serpentine areas have been surveyed and 7 soil samples taken from various depths of soil profiles. In addition to this, the entire flora present at studied locations was collected, identified, air-dried, sieved to less than $2 \mathrm{~mm}$ and analyzed for heavy metals concentrations as well as for the content of Calcium and Magnesium. Soil samples were picked upon observing the presence of the plants. All soil samples were air-dried, ground and sieved to $2 \mathrm{~mm}$, then transported in polyethylene bags to the laboratory for further analysis.

Those samples were analyzed for total $\mathrm{Ca}, \mathrm{Cd}, \mathrm{Co}, \mathrm{Cr}, \mathrm{Cu}, \mathrm{Mn}, \mathrm{Ni}, \mathrm{Pb}, \mathrm{Fe}$ and $\mathrm{Zn}$. Results showed that each site exhibited a high concentration of one or more heavy metals.

The first site investigated was Vejshtine, situated in the south-west Kosovo, lyingat an altitude of $632 \mathrm{~m}$ above the sea level and belonging to the continental climate with an average annual precipitation of 604 $\mathrm{mm}$. The average temperature is $10^{\circ} \mathrm{C}$ with its lowest $-1.3^{\circ} \mathrm{C}$ in January and its highest $20.4^{\circ} \mathrm{C}$ in July. The area is characterized by poor vegetation. In this area one soil profile was dug and two soil samples were taken, one for each horizon. The depth of profile was $0.6 \mathrm{~m}$ with bedrock lying underneath. The second 
investigated site was Çabër, situated in the southern part of Kosovo at an elevation of $587 \mathrm{~m}$, where one soil profile was dug and three samples of soil were taken. The third investigated site was Radoniq, a location situated in the western part of Kosovo, at an elevation of $455 \mathrm{~m}$. In this sampling site one soil profile was dug and 2 soil samples were taken at two different horizons. All soil and plants' samples were air-dried, then ground and sieved to $2 \mathrm{~mm}$ or less. Subsequently, they were mineralized with a microwave digester. Conditions for mineralization were $6 \mathrm{ml} \mathrm{HCl}, 2 \mathrm{ml} \mathrm{HNO}_{3}$, and $3 \mathrm{ml} \mathrm{H}_{2} \mathrm{O}_{2}$, per 0.5-g soil. Soils were air-dried and sieved to $2 \mathrm{~mm}$. Total major ( $\mathrm{Ca}, \mathrm{Mg}$ ) and trace elements $(\mathrm{Ni}, \mathrm{Cr}, \mathrm{Cu}, \mathrm{Zn}, \mathrm{Co}, \mathrm{Pb}, \mathrm{Cd}$, Fe and $\mathrm{Mn}$ ) were determined in mineralization solution by applying atomic absorption spectrophotometry. $\mathrm{Ni}$, Ca and Mg bioavailability in different soil samples was extracted by Mehlich 3 method (Schroder et al., 2010)

\section{RESULTS AND DISCUSSIONS}

\section{a) Trace elements}

The serpentine soils at all sites were characterized by elevated levels of heavy metals that show typical properties of ultramafic environments.

Results showed that each site exhibited a high concentration of at least one heavy metal. The maximum concentrations of $\mathrm{Cd}$ in soils dry matter (DM) were $108.9 \mathrm{mg} \mathrm{kg}^{-1}$ varying between 8.9 and $108.9 \mathrm{mg} \mathrm{kg}^{-1}$ The DM value was relatively high compared to the values generally observed in non-serpentine soils and considered toxic according to Kabata-Pendias and Pendias (1992). Its highest value was observed at Çabër location.

Table 1. Heavy metals, $\mathrm{Ca}$ and $\mathrm{Mg}$ concentrations and $\mathrm{pH}$ in soils

\begin{tabular}{|c|c|c|c|c|c|c|c|c|c|c|c|c|}
\hline \multirow[t]{2}{*}{ Site } & \multicolumn{7}{|c|}{$\mathrm{mg} \mathrm{kg}^{-1} \mathrm{DM}$} & & & \multicolumn{2}{|c|}{ \% DM } & \multirow[b]{2}{*}{$\mathrm{pH}$} \\
\hline & $\mathrm{Zn}$ & $\mathrm{Cd}$ & Co & $\mathrm{Cu}$ & $\mathrm{Ni}$ & $\mathbf{P b}$ & $M n$ & $\mathrm{Cr}$ & $\mathrm{Fe}$ & $\mathrm{Ca}$ & $\mathrm{Mg}$ & \\
\hline Vejshtine HA & 32.7 & 8.9 & 62.9 & 24.0 & 1543 & 21.7 & 1013 & 1150 & 4.87 & 0.37 & 17.90 & 8.58 \\
\hline Vejshtine HB & 26.6 & 84.3 & 71.5 & 21.4 & 2008 & 9.1 & 780 & 1206 & 5.06 & 0.54 & 18.70 & 8.64 \\
\hline Çaber HA & 39.0 & 103.1 & 82.8 & 14.4 & 2235 & 11.2 & 910 & 680 & 5.15 & 0.18 & 17.80 & 7.95 \\
\hline Çaber HB & 31.7 & 108.9 & 95.8 & 10.0 & 2570 & 9.2 & 898 & 218 & 4.50 & 0.07 & 19.20 & 7.88 \\
\hline Çaber HC & 25.7 & 94.8 & 54.2 & 5.4 & 1865 & 9.0 & 563 & 260 & 3.65 & 0.17 & 19.30 & 7.97 \\
\hline Radoniq HA & 31.7 & 67.2 & 78.8 & 9.2 & 2234 & 20.7 & 965 & 770 & 3.93 & 0.18 & 16.00 & 7.58 \\
\hline Radoniq HB & 20.4 & 66.8 & 49.5 & 8.3 & 1576 & 9.3 & 508 & 399 & 2.43 & 0.06 & 19.40 & 7.79 \\
\hline
\end{tabular}

$\mathrm{Cr}$ concentrations in soils were also elevated and varied from 218 to $1206 \mathrm{mg} \mathrm{kg}^{-1}$ of DM.

Total $\mathrm{Ni}$ availability at studied areas varied between 1543 and $2570 \mathrm{mg} \mathrm{kg}^{-1}$ respectively, whereas bioavailable $\mathrm{Ni}$ is at range of $37.71 \mathrm{mg} \mathrm{kg}^{-1}$ and $101.04 \mathrm{mg} \mathrm{kg}^{-1}$ respectively (Çabër).

The $\mathrm{Mn}$ content at all sites was rather homogenously distributed and varied between $508-1013 \mathrm{mg} \mathrm{kg}^{-1}$

Co presence in soil varied from $49.5-95.8 \mathrm{mg} \mathrm{kg}^{-1}$, being thus within the normal range for mafic rocks. Relatively easy interactions of Co with all metals that are associated geochemically or biochemically with Fe have a significant impact on its behavior in soils and its phytoavailability (Kabata-Pendias, 2011.

Iron concentration at all sampling sites showed typical ultramafic characteristics and varied from 2.43$5.15 \%$, while most of the total $\mathrm{Cu}, \mathrm{Zn}$, and $\mathrm{Pb}$ concentrations in analyzed serpentine soil samples fall within the normal soils' range.

Soil Ca ranged from $0.06-0.54 \%$, whilst total Mg concentrations were 16-19.4\%. As we have anticipated, all serpentine soils were characterized by extremely low $\mathrm{Ca} / \mathrm{Mg}$ quotients in the range of 0.003-0.02.

Robinson et al., (1935) and Brooks, (1987) suggested that high levels of phytotoxic elements such as nickel, chromium and cobalt in serpentine soils were responsible for their infertility.

There are several factors that contribute to phytotoxicity of heavy metals and their mobility through the soil horizons. One of the most important factors is the $\mathrm{pH}$ of the soil. In this study the $\mathrm{pH}$ of all soil samples 
is predominantly basic and varies from 7.58 to 8.64 , which shows that heavy metals mobility through the horizons of soil profile is very low when it comes to the $\mathrm{pH}$ readings.

If we refer to the papers published by (Bani et al., 2010; Bani et al., 2013) serpentine soils of Albania do not show any big difference in Ni content (1370-3240 $\mathrm{mg} \mathrm{kg}^{-1)}$ and 1658-3077) when compared to Kosovo's serpentine regions (1543-2570 $\left.\mathrm{mg} \mathrm{kg}^{-1}\right)$. Furthermore, if we compare the general presence of heavy metals in soils of Albania based on (Shallari et al., 1998) paper, there is no big difference in their contents either.

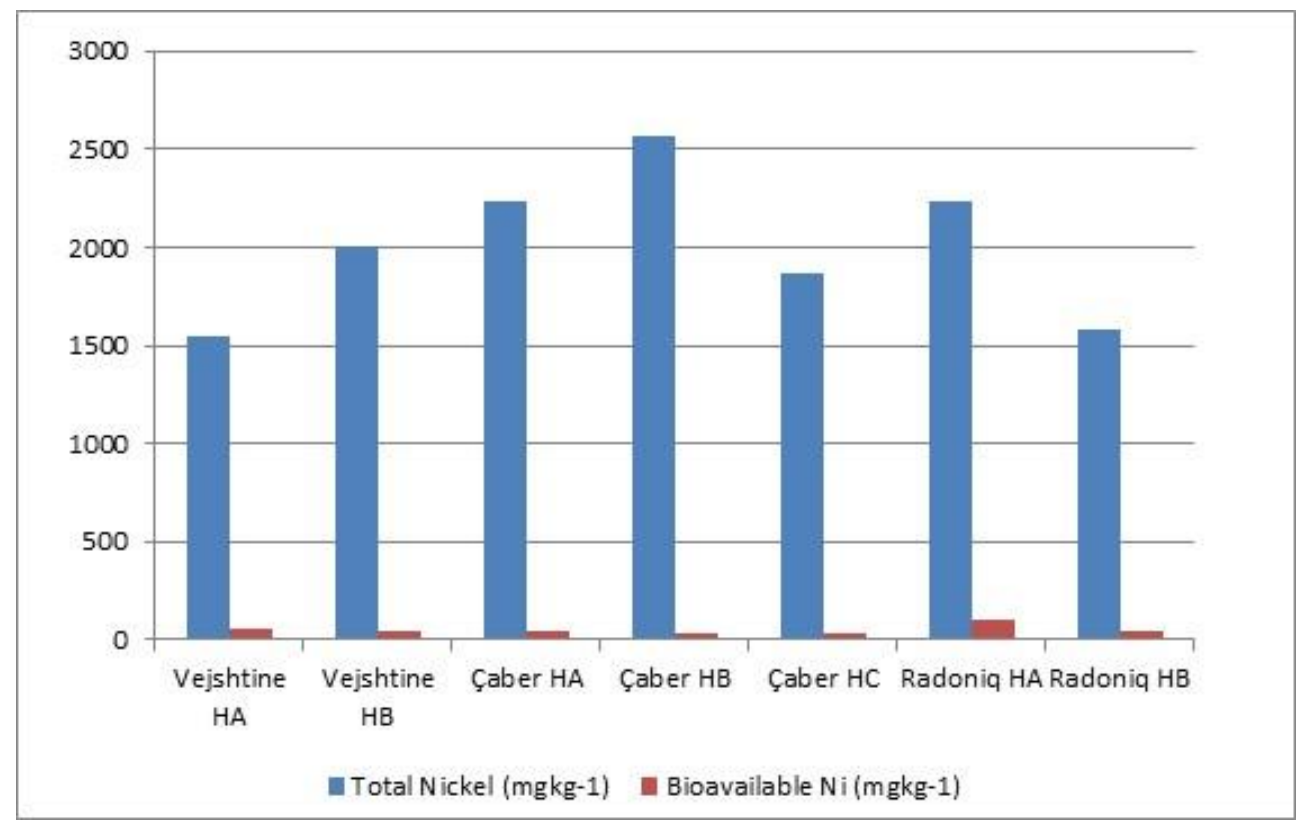

Figure 1. Total and Bioavailable Nickel proportion in serpentine soils

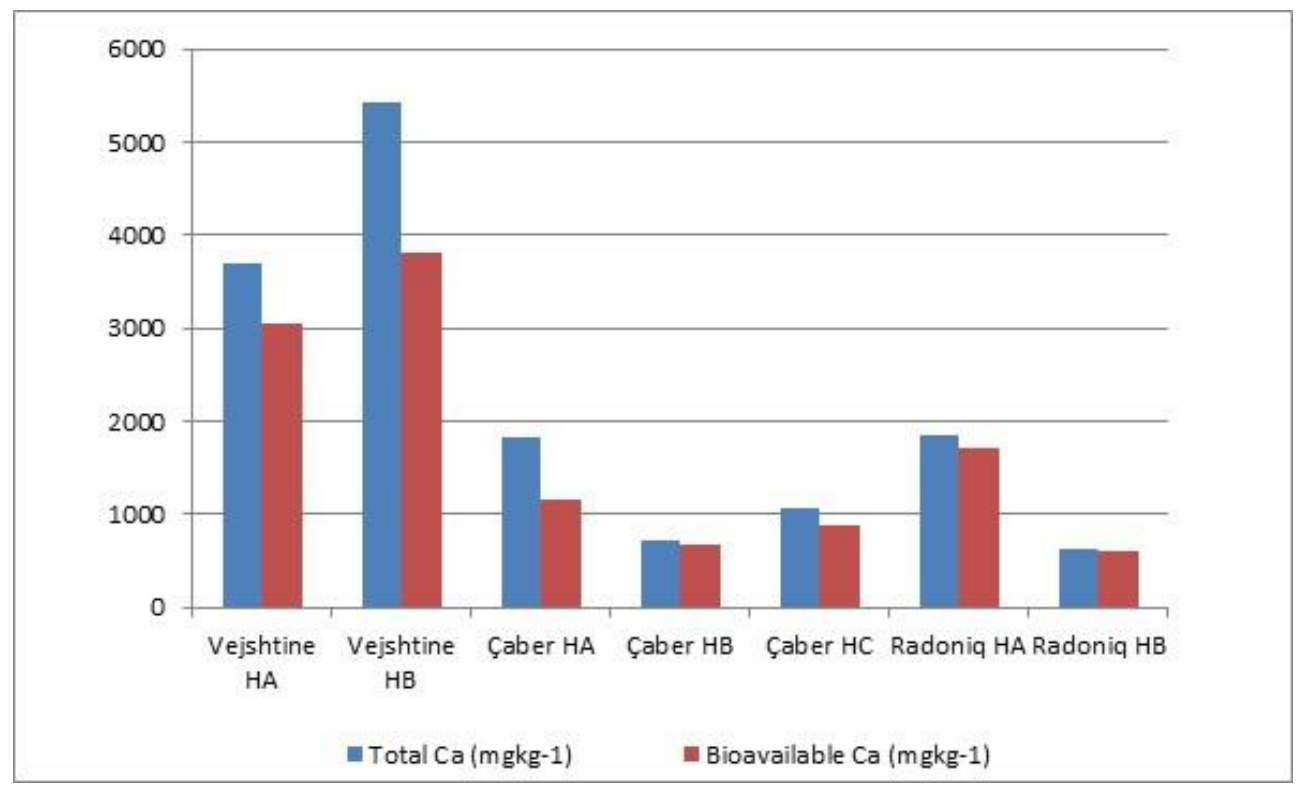

Figure 2. Total and Bioavailable Calcium proportion in serpentine soils 


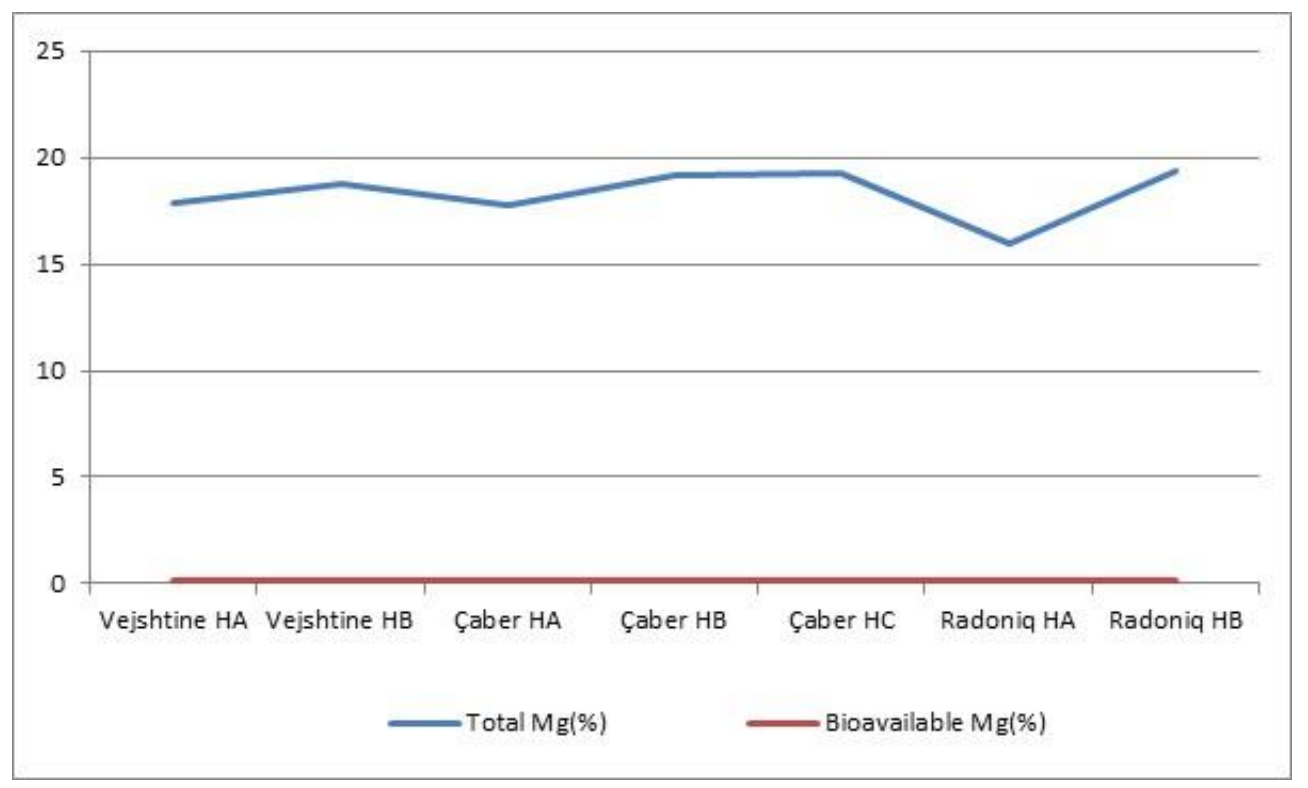

Figure 3. Total and Bioavailable Magnesium proportion in serpentine soils

\section{Standard deviation of Nickel content in soil samples}

Even though the serpentine soils are characterized by elevated levels of Nickel, Chromium and Cobalt, my attention will be focused on calculation of total Nickel content in soil and Ni uptake by hyperaccumulators plants

The formula for sample standard deviation

$$
s=\sqrt{\frac{1}{N-1}} \sum_{i=1}^{N}(x i-\bar{x}) 2
$$

The mean of Nickel content in soil is:

$(1543+2008+2235+2570+1865+2234+1576) / 7=2004 \mathrm{mg} \mathrm{kg}^{-1}$

So, $\bar{x}=2004$

Following subtraction and squaring the sample variance is: 140276

Whose square root is: $s=374$

Ni uptake by the hyperaccumulator plants species

Table 2 shows analysis performed on aerial part of plants. The highest Ni concentrations were recorded in Alyssum markgrafii which was the dominant species in all serpentine sites examined in this study. $\mathrm{Ni}$ uptake at Alyssum markgrafii varied from $1585.6-4038.5 \mathrm{mg} \mathrm{kg}^{-1}$ which is lower than Ni concentration found in the same species of serpentines of Albania (from 5234 to $12691 \mathrm{mg} \mathrm{kg}^{-1}$ ) (Bani et al., 2013). Ni uptake at Thlaspi sp. is $798.7 \mathrm{mg} \mathrm{kg}^{-1}$. If we compare this number with those from other serpentine regions of the Balkans we will see that $\mathrm{Ni}$ concentration of Thlaspi sp. found in Kosovo is lower than in Albania (1360 mg kg-1) or Thlaspi species found in Bulgaria (3400 mg kg-1) (Bani et al., 2010; Pavlova et al., 2010).The reason why Ni uptake is so low at Thlaspi sp. is delay in sample collection, as the maximum content of $\mathrm{Ni}$ in hyperaccumulator plants is in blooming stage, which is in early May for this species, whereas the sample collection happened in mid-June.Calcium concentrations in aerial part of Alyssum markgrafii were very high despite low concentration of $\mathrm{Ca}$ in soil. In the present work we obtained readings as high as $2.03 \%$ for $A$. markgrafii and $1.48 \%$ for Thlaspi sp.

The $\mathrm{Mg}$ concentration for the Alyssum markgrafii was in the range $0.23-0.62 \%$, while the one for Thlaspi was lower $(0.17 \%)$. This may be simply a reflection of the extraordinary uptake of Ca by both species. 
Basically the $\mathrm{Ca} / \mathrm{Mg}$ ratios to Nickel hyperaccumulator plants are greater than one $(>1)$, which is in contrast with serpentine associated soils. This ratio was in the range 2.21-6.78 for Alyssum markgrafii, and 8.70 for Thlaspi. Positive $\mathrm{Ca} / \mathrm{Mg}$ ratio has also been observed at Albanian Alyssum markgraffi (1.01) (Shallari et al., 1998).

High Calcium contents in these hyperaccumulator plants are the consequence of the unusual ability of these plants to accumulate high Ca concentration in their tissues, even from the soils with low $\mathrm{Ca} / \mathrm{Mg}$ ratio, which is a characteristic feature of serpentine soils. Thanks to this capability these plants are able to lower their Ca deficiency stress on their own.

Comparison of available concentrations of $\mathrm{Ni}$ in soils and in Alyssum markgrafii plant tissues (aerial part) as well as assessment of accumulation capacity for $\mathrm{Ni}$ are presented in Figure 4 . Ratio between $\mathrm{Ni}$ concentrations in aerial part of alyssum and its concentration in soil revealed variation among analyzed samples; the lowest ratio was 40.8 (Caber) and highest one 76.6 (Vejshtine). The accumulation factor (AF) is the ratio between trace elements concentration in plant tissues and their bioavailable concentration in the corresponding soil.

Accumulation factor is calculated with relation:

$\mathrm{AF}=\mathrm{Cp} / \mathrm{Cs}$

where: $\mathrm{Cp}$ is the mean metal concentration in alyssum markgraffi sample $\left(\mathrm{mg} \mathrm{kg}^{-1}\right)$ and $\mathrm{Cs}$ is the mean metal concentration available in soil sample $\left(\mathrm{mg} \mathrm{kg}^{-1}\right)$.

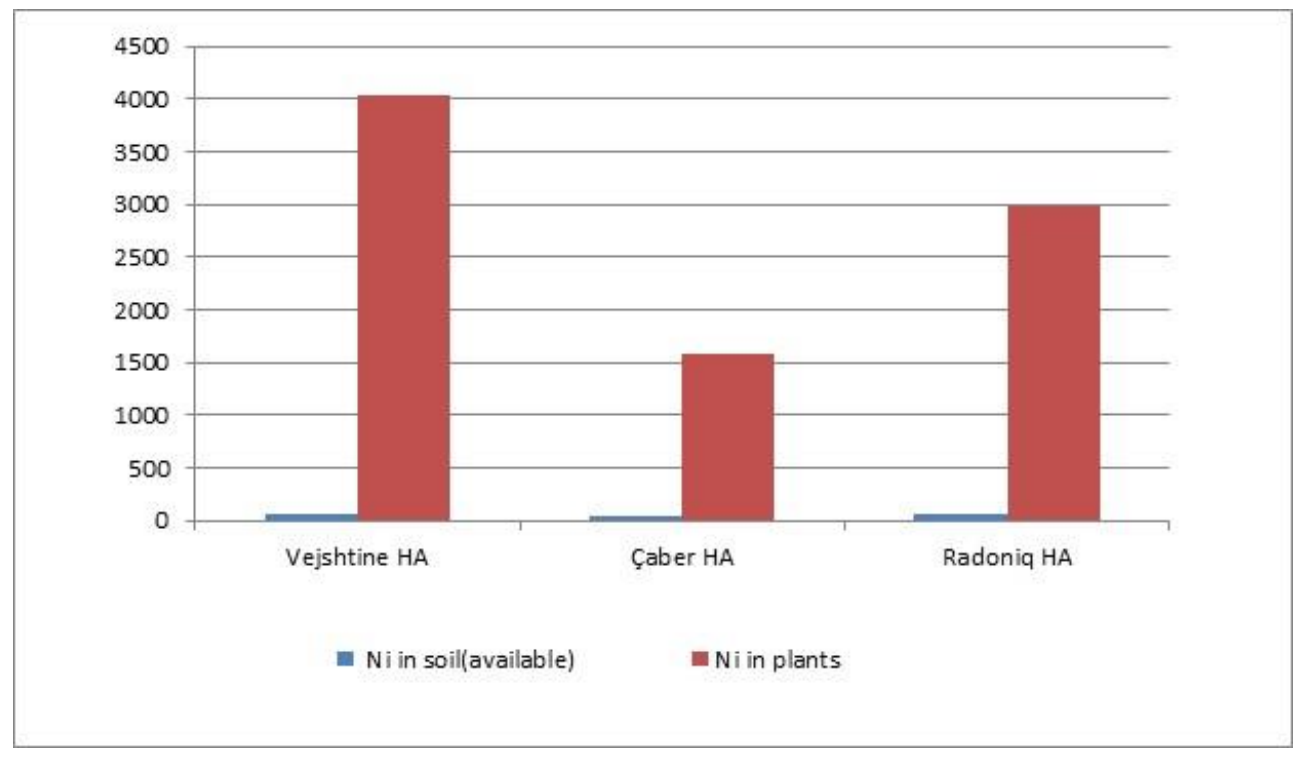

Figure 4. Ratio between bioavailable $\mathrm{Ni}$ in soil and $\mathrm{Ni}$ accumulation in Alyssum

Standard deviation of Nickel uptake by alyssum markgrafii

The mean of Nickel uptake by alyssum markgrafii is:

$(4038.5+1585.6+2980.2) / 3=2868.1 \mathrm{mg} \mathrm{kg}^{-1}$

$$
s=\sqrt{\frac{1}{N-1}} \sum_{i=1}^{N}(x i-\bar{x}) 2
$$

Following subtraction and squaring the sample variance will be 1531604 , whose square root is: $s=1230$ 
Table 2. Heavy metals, $\mathrm{Ca}, \mathrm{Mg}$ concentrations in plants collected at serpentine sites

\begin{tabular}{|c|c|c|c|c|c|c|c|c|c|c|c|c|}
\hline \multirow[t]{2}{*}{ Site } & \multirow[t]{2}{*}{ Species } & \multicolumn{9}{|c|}{$\mathrm{mg} \mathrm{kg}^{-1}$} & \multicolumn{2}{|c|}{$\% \mathrm{DM}$} \\
\hline & & $\mathrm{Zn}$ & $\mathrm{Cd}$ & $\mathrm{Mn}$ & $\mathrm{Ni}$ & $\mathrm{Cu}$ & $\mathrm{Pb}$ & Mo & $\mathrm{Cr}$ & Co & $\mathrm{Ca}$ & $\mathrm{Mg}$ \\
\hline \multirow{23}{*}{ Vejshtine } & Alyssum alysoides & 15.05 & $<1$ & 16.39 & 8.1 & 2.89 & 5.28 & $<1$ & 4.36 & $<1$ & 1.47 & 0.20 \\
\hline & Alyssum markgrafii & 143.29 & $<1$ & 38.2 & 4038.5 & 2.74 & 6.11 & 14.26 & 38.1 & $<1$ & 0.51 & 0.23 \\
\hline & Asperula Arvensis & 24.57 & $<1$ & 31.59 & 13.13 & 5.11 & 5.75 & $<1$ & 8.58 & $<1$ & 0.61 & 0.25 \\
\hline & Bromus inermis Lays. & 19.04 & $<1$ & 83.89 & 30.19 & 3.48 & 5.44 & $<1$ & 36.35 & 3.18 & 0.19 & 0.25 \\
\hline & Carex Paniculata & 16.86 & $<1$ & 68.11 & 75.72 & 4.15 & 7.63 & $<1$ & 72.39 & 4.4 & 0.19 & 0.66 \\
\hline & Corydalis lutea & 23.57 & 1.5 & 136.11 & 15.59 & 4.68 & 7.63 & $<1$ & 9.75 & $<1$ & 0.45 & 0.27 \\
\hline & Crepis aurea & 23.06 & $<1$ & 65.45 & 96.71 & 8.07 & 12.76 & $<1$ & 39.73 & 3.49 & 2.13 & 0.49 \\
\hline & Dorycnium pentaphyllum & 19.34 & 1.4 & 40.35 & 28.68 & 6.5 & 5.79 & 19.09 & 5.3 & $<1$ & 0.76 & 0.18 \\
\hline & Echium rubrum & 31 & $<1$ & 98.55 & 69.61 & 8.33 & 23.84 & $<1$ & 87.72 & 4.31 & 1.97 & 0.40 \\
\hline & Euphorbia helioscopia & 28.06 & $<1$ & 60.89 & 50.15 & 6.62 & 7.3 & $<1$ & 13.27 & 3.03 & 1.21 & 0.30 \\
\hline & Fumana procumbens & 21.75 & $<1$ & 60.92 & 66.96 & 6.58 & 9.26 & $<1$ & 46.16 & 6.14 & 0.83 & 0.51 \\
\hline & Galium cruciata & 22.38 & $<1$ & 33.92 & 18.12 & 9.28 & 6.72 & $<1$ & 16.58 & $<1$ & 0.63 & 0.20 \\
\hline & $\begin{array}{l}\text { Helianthemum } \\
\text { Numularium }\end{array}$ & 20.53 & $<1$ & 48.49 & 21.42 & 8.86 & 7.32 & $<1$ & 25 & $<1$ & 0.83 & 0.20 \\
\hline & Illecebrum verticillatum & 27.02 & 1.8 & 82.78 & 11.63 & 3.37 & 8.39 & $<1$ & 20.19 & $<1$ & 0.49 & 0.27 \\
\hline & Potentilla arenaria & 34.73 & $<1$ & 129.41 & 102.03 & 7.49 & 14.86 & $<1$ & 68.37 & 4.85 & 0.91 & 0.62 \\
\hline & Rumex acetosella & 20.9 & $<1$ & 39.82 & 23.88 & 3.49 & 6.64 & $<1$ & 18.55 & $<1$ & 0.42 & 0.29 \\
\hline & Sanguisorba minor scop. & 17.6 & $<1$ & 37.55 & 13.53 & 5.09 & 7.25 & $<1$ & 12.22 & $<1$ & 0.87 & 0.46 \\
\hline & Scorzonera humilis & 36.77 & $<1$ & 59.64 & 25.77 & 7.89 & 9.36 & $<1$ & 27.8 & $<1$ & 1.17 & 0.25 \\
\hline & Sedum album & 9.47 & $<1$ & 21.32 & 22.42 & 3.97 & 5.74 & $<1$ & 11.97 & $<1$ & 1.17 & 0.23 \\
\hline & Sedum atratum & 20.83 & $<1$ & 51.71 & 54.35 & 6.81 & 17.68 & $<1$ & 79.7 & 3.74 & 3.35 & 0.66 \\
\hline & Stipa pennata & 16.71 & $<1$ & 31.9 & 8.23 & 5.21 & 6.48 & $<1$ & 92.72 & $<1$ & 0.22 & 0.05 \\
\hline & Thalictrum minus & 23.52 & $<1$ & 25.77 & 8.63 & 9.23 & 5.25 & $<1$ & 6.72 & $<1$ & 0.49 & 0.11 \\
\hline & Thymus pulegioides & 34.19 & $<1$ & 47.12 & 24.46 & 6.83 & 11.3 & 1.81 & 16.12 & $<1$ & 0.83 & 0.21 \\
\hline \multirow{8}{*}{ Çabër } & Alyssum markgrafii & 30.84 & $<1$ & 70.24 & 1585.6 & 1.24 & $<1$ & 2.03 & $<1$ & 38.07 & 2.03 & 0.62 \\
\hline & Astragalus onobrychis & 13.63 & $<1$ & 82.77 & 64.96 & 4.47 & 2.14 & 7.41 & $<1$ & 24.51 & 0.38 & 0.70 \\
\hline & Carex paniculata & 17.95 & $<1$ & 49.1 & 48.22 & 3.48 & $<1$ & 8.49 & $<1$ & 28.22 & 0.15 & 0.35 \\
\hline & Crepis aurea & 20.37 & $<1$ & 35.88 & 21.98 & 6.57 & $<1$ & 7.18 & $<1$ & 16.87 & 1.24 & 0.58 \\
\hline & Dorycnium pentaphyllum & 30.52 & $<1$ & 79.56 & 40.3 & 7.98 & $<1$ & 7.01 & $<1$ & 14.47 & 0.72 & 0.32 \\
\hline & Echium rubrum & 14.52 & $<1$ & 56.22 & 63.1 & 5.51 & $<1$ & 6.34 & $<1$ & 49.2 & 1.66 & 0.46 \\
\hline & Euphorbia amygdaloides & 17.36 & $<1$ & 36.78 & 44.31 & 3.73 & 3.1 & 9.36 & $<1$ & 23.3 & 0.93 & 0.46 \\
\hline & Illecebrum verticillatum & 15.74 & $<1$ & 106.45 & 32.15 & 3.33 & $<1$ & 9.17 & $<1$ & 29.98 & 0.36 & 0.39 \\
\hline
\end{tabular}




\begin{tabular}{|c|c|c|c|c|c|c|c|c|c|c|c|c|}
\hline \multirow{31}{*}{ Radoniq } & Juniperus communis & 7.91 & $<1$ & 45.37 & 19.76 & 3.49 & $<1$ & 6.06 & $<1$ & 17.99 & 0.72 & 0.16 \\
\hline & Linum tauricum & 21.22 & $<1$ & 40.45 & 44.29 & 6.04 & $<1$ & 6.82 & $<1$ & 13.27 & 0.25 & 0.50 \\
\hline & Potentilla argentea & 20 & $<1$ & 48.12 & 27.6 & 5.21 & $<1$ & 7.22 & $<1$ & 8.74 & 0.69 & 0.39 \\
\hline & Potentilla visianii & 21.78 & $<1$ & 24.54 & 18.4 & 7.19 & $<1$ & 6.85 & $<1$ & 3.32 & 0.31 & 0.19 \\
\hline & Sedum atratum & 13.97 & $<1$ & 26.23 & 22.42 & 4.22 & $<1$ & 8.78 & $<1$ & 8.79 & 1.79 & 0.46 \\
\hline & Silene pusilla W.et $K$. & 9.1 & $<1$ & 73.16 & 28.28 & 3.59 & $<1$ & 9.06 & $<1$ & 14.12 & 0.94 & 0.43 \\
\hline & Stachys officinalis & 15.63 & $<1$ & 33.83 & 35.06 & 8.49 & $<1$ & 8.12 & $<1$ & 10.43 & 0.39 & 0.31 \\
\hline & Thymus pulegioides & 24.98 & $<1$ & 88.35 & 61.52 & 6.36 & $<1$ & 8.48 & $<1$ & 25.98 & 0.57 & 0.42 \\
\hline & Trifolium dubium sibth. & 7.56 & $<1$ & 33.93 & 34.12 & 4.6 & $<1$ & 7.23 & $<1$ & 12.99 & 0.61 & 0.48 \\
\hline & Alyssum markgrafii & 70.2 & $<1$ & 23.99 & 2980.2 & 2.73 & $<1$ & 5.17 & 8.69 & 11.28 & 1.56 & 0.23 \\
\hline & Astragalus onobrychis & 10.69 & $<1$ & 47.89 & 49.14 & 5.07 & $<1$ & 5.18 & 5.42 & 27.24 & 0.50 & 0.22 \\
\hline & Carex paniculata & 24.29 & $<1$ & 34.93 & 31.61 & 5.32 & 1.5 & 2.81 & 14.32 & 41.14 & 0.16 & 0.21 \\
\hline & Chamomilla recutita & 35.26 & $<1$ & 27.96 & 21.97 & 9.54 & $<1$ & 3.33 & 10.67 & 13.68 & 1.23 & 0.22 \\
\hline & Cirsium canum & 51.78 & $<1$ & 52.66 & 39.16 & 9.06 & 1.3 & 6.34 & $<1$ & 45.3 & 1.26 & 0.60 \\
\hline & Crepis aurea & 20.86 & $<1$ & 27.73 & 21.3 & 7.86 & $<1$ & 4.09 & $<1$ & 22.17 & 0.99 & 0.27 \\
\hline & Dorycnium pentaphyllum & 13.31 & $<1$ & 51.06 & 22.88 & 5.27 & 1.2 & 4.34 & 2.71 & 10.24 & 0.63 & 0.21 \\
\hline & Galium verum & 17.79 & $<1$ & 23.08 & 8.28 & 4.55 & $<1$ & 2.95 & $<1$ & 33.47 & 0.72 & 0.09 \\
\hline & Gentista tinctoria & 14.03 & $<1$ & 43.89 & 18.13 & 4.51 & $<1$ & 3.9 & 5.99 & 18.01 & 1.02 & 0.30 \\
\hline & Hypericum perforatum & 30.54 & 1.3 & 35.09 & 51.06 & 9.8 & $<1$ & 6.27 & 7.82 & 17.23 & 0.39 & 0.16 \\
\hline & Melisa ciliate & 19.62 & $<1$ & 52.96 & 10.2 & 3.05 & $<1$ & 5.08 & $<1$ & 9.6 & 0.10 & 0.06 \\
\hline & Phleum Phleoides & 18.83 & $<1$ & 16.5 & 7.84 & 3.83 & $<1$ & 3.7 & $<1$ & 7.05 & 0.09 & 0.03 \\
\hline & Plantago lanceolata & 27.68 & $<1$ & 30.81 & 21.92 & 5.65 & $<1$ & 4.62 & 4.62 & 29.45 & 0.54 & 0.33 \\
\hline & Potentilla recta & 20.19 & 2.4 & 31.69 & 10.2 & 5.67 & $<1$ & 6.37 & $<1$ & 7.45 & 1.60 & 0.19 \\
\hline & Rumex acetosella & 15.62 & $<1$ & 42.81 & 31.43 & 3.82 & $<1$ & 6.72 & 5.09 & 23.26 & 0.20 & 0.34 \\
\hline & Sanguisorba minor scop. & 15.22 & $<1$ & 25.69 & 11.47 & 4.71 & $<1$ & 6.29 & 11.8 & 6.47 & 1.30 & 0.22 \\
\hline & Sedum ochroleucum & 12.45 & $<1$ & 24.26 & 32.01 & 3.29 & $<1$ & 7.2 & $<1$ & 26.6 & 1.49 & 0.42 \\
\hline & Solidago virgaurea & 13.03 & 3.6 & 28.2 & 5.8 & 4.18 & $<1$ & 6.44 & $<1$ & 3.59 & 0.45 & 0.16 \\
\hline & Stachys scardica & 71.23 & 4.1 & 68.46 & 48.6 & 11.87 & $<1$ & 7.46 & 5.95 & 15.47 & 0.46 & 0.32 \\
\hline & Thlaspi perfoliatum & 593.24 & $<1$ & 38.2 & 798.7 & 2.79 & $<1$ & 3.54 & 14.3 & 38.1 & 1.48 & 0.17 \\
\hline & Thymus pulegioides & 31.42 & 3.1 & 60.24 & 178.21 & 5.87 & $<1$ & 5.63 & $<1$ & 21.97 & 0.52 & 0.41 \\
\hline & Trifolium alpestre & 13.99 & $<1$ & 85.61 & 16.23 & 4.74 & $<1$ & 6.85 & $<1$ & 4.64 & 0.96 & 0.26 \\
\hline
\end{tabular}




\section{Conclusions}

Based on site surveys Kosovo serpentine flora is more peculiar when compared to adjacent nonserpentine areas. Presence of hyperaccumulator plants is not very diverse. Alyssym markgrafii and Thlaspi $s p$ are the dominant species, with the latter one not being present in all serpentine areas, but rather found here and there. Based on our findings from the field we concluded that there is a close relationship between the quantity of $\mathrm{Ni}$ in soil and $\mathrm{Ni}$ uptake in plants, but not as close as it is in the serpentines of Albania. The Ni amount in plants is twice as much as in associated soil. These plants species can be used for phytostabilization and phytoremediation of contaminated areas by anthropogenic factor. Ultramafic areas in Kosovo, such as those examined for the present study, have been studied in less detail than many others in terms of phytoextraction, at least until recently; hence we have to intensify our research in this field in future.

Results from the field have proved that the following two out of three most popular hypotheses presented by Kazakou et al. 2010 have been met: Low availability of calcium in relation to magnesium; Deficiency of essential macronutrients and High levels of phytotoxic heavy metals ( $\mathrm{Ni}, \mathrm{Cr}, \mathrm{Co}, \mathrm{Mn}, \mathrm{Co}$ ).

Serpentine soils have properties that are highly unfavorable for most plants, amongst which, the heavy metal tolerance, especially to $\mathrm{Ni}$, is considered to be the crucial factor for plant survival in certain serpentine soils (Kruckeberg 1954; Proctor and Woodell 1975).

\section{References}

Bani A. and Pavlova D. (2010), Nickel hyperaccumulation by the species of Alyssum and Thlaspi (Brassicaceae) from the ultramafic soils of the Balkans, Botanica Serbica, 34(1), 3-14.

Bani A., Imeri A., Echevarria G., Pavlova D., Reeves R.D., Morel J.L. and Sulçe S. (2013), Nickel hyperaccumulation in serpentine Flora of Albania, Fresenius Environmental Bulletin, 22(6), 1792 - 1801.

Brooks R.R. (1987), Serpentine and its vegetation. A Multidisciplinary Approach. Dioscorides Press, Portland.

Kabata-Pendias A. and Pendias H. (1992), Trace elements in soils and plants. Boca Rabton. FL: CRC Press, 131-133.

Kabata-Pendias, A. (2011): Trace elements in soils and plants. 4th ed. - CRC Press. Taylor \& Francis Group, Boca Raton. London, New York.

Kazakou E. and Dimitrakopoulos P.G. (2010), Species adaptation in serpentine soils in Lesbos Island (Greece): metal hyperaccumulation and tolerance, Plant and Soil, 332, 369-385.

Krause, W. (1958): Encyclopedia of Plant Physiology, Springer, Berlin, 755-806, (in German).

Kruckeberg A.R. (1954), The ecology of serpentine soils: A symposium. III. Plant species in relation to serpentine soils, Ecology, 35, 267-274.

Loew O. and May D.W. (1901), The relation of lime and magnesia to plant growth, US Dep. Agric. Bur. Plant Ind., Bull. 1, 1-53.

Proctor J. (1971), The Plant Ecology of Serpentine: III. The Influence of a High Magnesium/Calcium Ratio and High Nickel and Chromium Levels in Some British and Swedish Serpentine Soils, Journal of Ecology, 59(3), 827-842.

Proctor J. and Woodell S.R.J. (1975), The ecology of serpentine soils, Advances in Ecological Research, 9, 255-365.

Robinson W.O., Edgington G. and Byers H.G. (1935), Chemical studies of infertile soils derived from rocks high in magnesium and generally high in chromium and nickel. U.S. Dept. Agr. Tech., Bull. 471.

Schroder J.L., Zhang H., Richards J.R. and Payton M.E. (2009), An inter-laboratory validation of Mehlich 3 as a universal extractant for plant nutrients, J. AOAC International, 92(4), 995-1008.

Shallari S., Schwartz C., Hasko A. and Morel J.L. (1998), Heavy metals in soils and plants of serpentine and industrial sites of Albania, Science of the Total Environment, 209(2-3), 133-142. 